\title{
Using Puppet Games in Teaching Speaking for Tenth Graders of Senior High School
}

\author{
Dania Yolanda'), Muhamad Sofian Hadi2) \\ 1) SMA Perjuangan, Sawangan, Depok, Indonesia \\ 2)Universitas Muhammadiyah Jakarta, Tangerang, Banten, Indonesia \\ 1)Daniayolanda13@gmail.com, 2)M_Sofianhadi@yahoo.com
}

\begin{abstract}
This research aimed to improve the students' speaking skill in English lesson by puppets games. This research was conducted by using Quasi-Experimental. The subject of this research was Class X MIPA of SMA Perjuangan Depok 2018/2019 academic year, which consisted of 29 students. The objective of this research was to teaching students' speaking skill in English Lesson by using Puppets Games at Ten Grade of SMA Perjuangan Depok. The data were gathered through quantitative and qualitative data. The result of this research showed that there was increasing of students in speaking skill. The mean of pre-test was 58.34. The mean of post-test was 77. Based on the result analysis, it can be concluded that there was a significance using puppets games in teaching speaking at tenth grade senior high school. The result showed that the result of T-test calculation is 13.090 more higher than T-table 5\%, it gained score 2.045. Therefore, it can be conclude that teaching speaking using puppets games is effective to improve speaking skill at the tenth grade of SMA Perjuangan Depok. The results of this study are expected to be useful to related parties such as principals, teachers, parents, students and further researchers.
\end{abstract}

Keywords: puppets, games, teaching speaking, students' speaking skill.

Citation APA Style: Yolanda, D., \& Hadi, M. S. (2019). Using Puppet Games in Teaching Speaking for Tenth Graders of Senior High School. English Language in Focus (ELIF), 2(1), 1-8.

\section{INTRODUCTION}

$\mathrm{E}$ nglish is an international language in the world. English has 4 skills; there are writing, listening, reading and speaking. Of the four skills, speaking English is very difficult in Indonesia. This is due to teaching methods and also the practice of speaking less efficiently. Nowadays, English has been taught in every school, starting from Junior High School and
Senior High School. In addition, English is also used to be one of the major subjects at university in Indonesia. Many people cannot speak English well in Indonesia because it is a foreign language for us. So as an English teacher, we must pay attention to the student' competence in English, especially, four language skills; speaking, reading, writing and listening.

In Indonesian schools, Teachingspeaking English must be emphasized 
more on students both in speaking and written. So that students can speak languages well. Richards (2012, p. 3) proposes that communication competencies consist of four aspects. There are linguistics, sociolinguistics, discourse, and strategic competence. The use of language and sentences aims to understand various types of texts and maintain communication even though they have limitations in communication. In communication, someone also uses language that is easily understood by others.

Language is supposed to be said not written so that it becomes a form of communication between humans. Every human being always starts by learning to speak first when she or he wants to learn others language. At school learning English is very important but sometimes many students who cannot speak English easily and well. That is why many students have difficulty learning English. Speaking is one of the skills that should be learned by students in learning English. Through speaking, they can express their ideas and communicate with others.

In speaking, the students learn how to organize the idea, express the language in the spoken form with good pronunciation and stressing. They also learn about how to convey the meaning of the language according to the context they are speaking. If we can speak English well, our communication will be better because the listener will understand what we talk about. Moreover, speaking and other skills need exercise and practice. Without exercise and practice, the students cannot be a good speaker.
Hence, a good speaker means that someone who can speak clearly and well. So, the other can understand what she/he talks about. In reality, the ability in speaking material does not meet the standard of curriculum. Their vocabulary, grammar, and pronunciation are low which make them unable to say something during the speaking class. Related to the competence of the students speaking proficiency, they are some indicators which show that they do not speak accurately.

In teaching speaking, the teacher must create a situation that can encourage the student to speak. There are many kinds of technique that can be used by the teacher in teaching speaking, the teacher can use many types of technique that can provide a lot of convenience in the field of speaking for students. One of the techniques that can be used by the teacher is games. Games can be a very useful teaching technique for effective and joyful learning. According to Wright (2013, p. 4), "write that games can help the teacher to create contexts in which their language is useful and meaningful". Games can help students to learn English practice easily and also relaxed.

For many years, English teachers teach or train students to speak about the repetition of vocabulary, good speaking and also training memory in dialogue. However; today's world requires that the goal of teaching speaking should improve students communicative skills because students can express themselves and learn how to follow the social and cultural rules appropriate in each communicative circumstance. 
There are some explanations about teaching speaking. According to Blestein \& Lewis (2015, p. 47), teaching speaking is to teach English language learners to produce English speech sounds and sound patterns;

1. Use words and sentence stress, intonation patterns and the rhythm of the second language.

2. Select appropriate words and sentences according to the proper social setting, audience, situation and subject matter.

3. Organize their thoughts in a meaningful and logical sequence.

4. Use language as a means of expressing values and judgments.

5. Use the language quickly and confidently with few unnatural pauses, which is called fluency.

According to Hughes \& Szczepek Reed (2017), the goal of teaching speaking is communicative in speaking. So, in learning English pronunciation (speaking) students must make themselves understood and must try not to be confused in pronunciation, vocabulary and also grammar to regulate the communication situation. According to Goh \& Burns (2012, p. 110), when teaching to speak, the teacher must be very competent in activities in the class and also motivate students. However, the teacher must make the speaking class more enjoyable. Teachers must make activities that are direct communication between students.

Huyen \& Nga (2013) stated that games also can be used in giving practice in all language skills and the use to practice any types of communication which in line with the objectives of teaching skills. The kind of games is finger games or finger plays . While playing finger games the development of students communicates skill is encouraged. Speaking skill and the development of interaction are closely linked, as successful interaction is not possible without well development language skills.

In this case, the teacher has the responsibility to guide students besides also giving students support and motivation so that they can improve their English skills. To solve the problem, there are many teaching methods to help teachers more easily convey material, for example by using media or games. This can make students easier to understand the material and concepts taught. The use of media allows students to better understand teaching material. Using media also makes students see themselves in the teaching and learning process. Some of the kinds of media that might help them to deliver the materials are song, picture, rhyme, models, puppets, etc.

Using puppet to learn about the oral language or speaking is the first application of puppet to learning language arts. Brainstorming about the students' puppet was the beginning of teaching them how to express their feelings and observations. Teacher can apply stimulation by having their students to create their own words by using puppet and then ask them question about the puppet's personalities. The students will be motivated to use their own words to describe their ideas using puppet. The teacher can help the students by tossing out new and unfamiliar vocabulary words and talking about the parts of speech to describe 
how the puppet act and feel. The teacher can also ask the students to touch, feel, and move their puppet around to become familiar with them and to ease the process of describing it.

Some of the most common and easiest puppets to make are stick puppets, hands puppets, finger puppets, people puppets, wooden spoon puppets, mitten and socks puppets, vegetable (fruit) puppets, Ping-Pong ball puppets and cylinder puppets, (Mayesky, 2011, p. 337; Wikipedia, n.d.). This is a way to help the students speak up to describe subject using their own words and their new vocabulary. The puppet used in the classroom can help to serve as a very effective aid for teaching language arts. Oral languages skills that selected can be developed through the use of puppet are parts of speech, vocabulary, public speaking, and expressions of thoughts and feelings (Narayanan, 2012).

Based on Celce-Murcia, Brinton, \& Snow (2014), some media can be used in teaching Speaking Some ways in prompting the speaking skill are sequence of picture which prompts their memory. Then, a sequence of picture these can be card picture or paper. A sequence of keywords, besides, mime, where students try to speak based on the gesture. Finally, teacher can use figurines or puppet, teacher and students operate the figure puppet. Puppet is one of the media to improve speaking. It can be used as a model especially performing in front of the class. The students can see the performance of the model first and then, they can imitate the performance.

The teacher can also ask the students to touch, feel, and move their puppet around to become familiar with them and to ease the process of describing it. This is a way to help the students speak up to describe subject using their own words and their new vocabulary. There are some advantages of using puppet in English speaking class:

1. The puppet can help to serve as a very effective aid for teaching language arts.

2. The puppet can bring about the development of any aspects of language in junior high school.

3. The puppet encourages students to talk and express their creative ideas verbally.

4. The puppet can help the students not only think of what to say but also feel comfortable when they are speaking.

5. The puppet is a way for students to speak in front of the other students without feeling intimidated.

6. The puppet gives the students a means to express themselves and their ideas without the stress of having something to completely understand that language.

7. The puppet can help the students to relate and play better with other students who speak English fluently (Kidspot, 2016).

\section{RESEARCH METHODOLOGY}

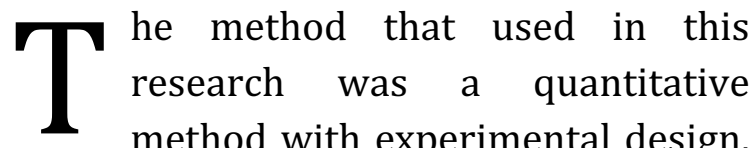
using one group for pre-test and posttest. So, the Writer only compared the score of students speaking skill before the treatment using Puppets Games and the score of students speaking skill after the treatment Puppets Games. This research was conducted in SMA Perjuangan Depok that is located on 
Depok Sawangan, West Java. It was conducted on the first semester in the academic year of 2018/2019 at tenth grade. In addition, the population of this study is all students at tenth-year students of SMA Perjuangan Depok, in academic year 2018/2019. The writer chosen one class for the investigation, that was class X-MIPA as an experiment class that consists of 29 students.

In collecting the data, both pretest and post-test will be used as the instrument. To know the basic of students' speaking skill, a pre-test was given before treatment. The treatment was using Puppets Games to improve students' speaking skill. The time spent to test and apply this method was 12 times meeting. In the last, post-test was conducted to find out students' speaking skill after getting the treatment. After collecting the data, the writer will analyze the results of the test statistically. A formula used in the study is t-test for one group which is also known as Paired Sample t-Test.

\section{FINDING AND DISCUSSION}

A fter the field research was conducted, the writer analyzed the data gained from the research. And the result of data analysis could be described as follows:

\section{Pre-test Result of Students' Speaking.}

After several experiments conducted at SMA Perjuangan Depok, the writer saw that the highest result of pretest in experimental class was 76. 2 Students obtained it. Then, the lowest result of pre-test in the experimental class was 48. And one Student obtained it. To make it easier, the writer-classified students speaking skill based on the following criteria. The Pre-Test score was presented in the table below:

Tabel 1. Pre-test Students speaking of conversation level

\begin{tabular}{cccc}
\hline \multicolumn{2}{c}{$\begin{array}{c}\text { Students speaking } \\
\text { of conversation } \\
\text { level }\end{array}$} & $\begin{array}{c}\text { Total } \\
\text { Number of } \\
\text { Students }\end{array}$ & $\begin{array}{c}\text { Percenta } \\
\text { ge of } \\
\text { Result }\end{array}$ \\
\hline $\begin{array}{c}\text { Upper } \\
\text { Score }\end{array}$ & $75-100$ & 2 & $7 \%$ \\
$\begin{array}{c}\text { Middle } \\
\text { Score }\end{array}$ & $60-74$ & 13 & $43 \%$ \\
$\begin{array}{c}\text { Lower } \\
\text { Score }\end{array}$ & $31-59$ & 14 & $50 \%$ \\
$\begin{array}{c}\text { Poor } \\
\text { Score }\end{array}$ & $0-30$ & 0 & $0 \%$ \\
\hline
\end{tabular}

Only 2 students got uppercase (75-100). There are 12 students got a middle score (60-74) and then, 14 students got lower score (31-59). Mean score gained by the students was 58,34. From the table analysis above, the students' speaking skill of English lesson was still low. From the criteria 2 students got upper score or it was only $7 \%$. Then 12 students got middle score only $43 \%$, on the other side 26 students lower score or it was $50 \%$. The spread of score was presented in the frequency distribution table 4.3:

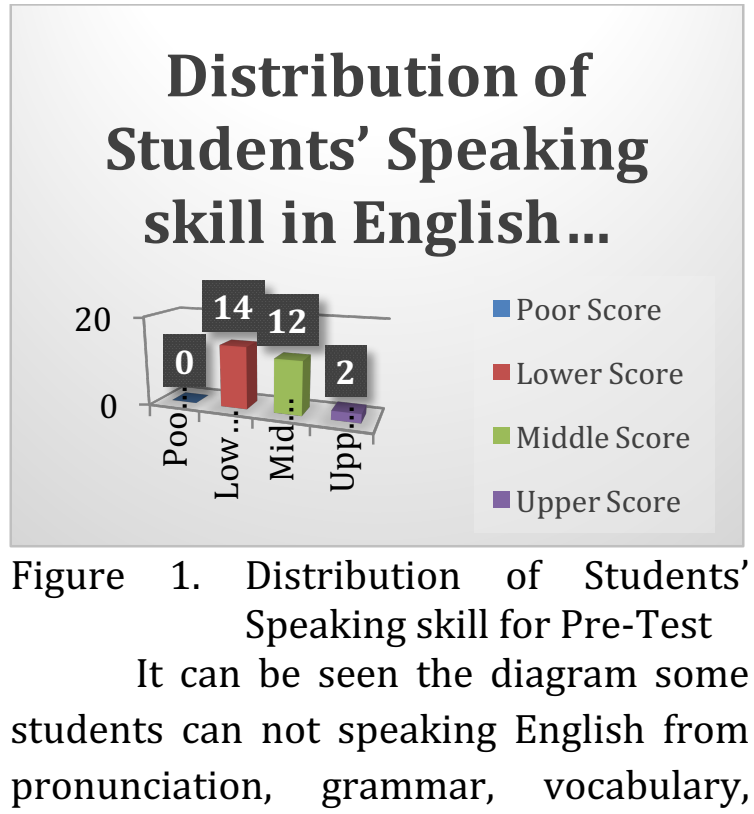


fluency and comprehension. After giving the test of conversation the writer will be applied the treatment using puppets games in speaking teaching.

\section{Post-test Result of Students' Speaking Skill.}

Post-test was given to see how far was the students' progress after the treatment using Puppets Games for 7 weeks. As a result, students' speaking skill in English lesson was good. The mean of students was 77 . Only 26 students got uppercase (75-100). There are 3 students got a middle score (60-74) and then, no one student got lower score (31-59). Mean score gained by the students was 77. The Pre-Test score was presented in the table below:

Tabel 2. Post-test Students speaking of conversation level

\begin{tabular}{cccc}
\hline \multicolumn{2}{c}{$\begin{array}{c}\text { Students speaking } \\
\text { of conversation } \\
\text { level }\end{array}$} & $\begin{array}{c}\text { Total } \\
\text { Number of } \\
\text { Students }\end{array}$ & $\begin{array}{c}\text { Percenta } \\
\text { ge of } \\
\text { Result }\end{array}$ \\
\hline $\begin{array}{c}\text { Upper } \\
\text { Score }\end{array}$ & $75-100$ & 23 & $79,31 \%$ \\
$\begin{array}{c}\text { Middle } \\
\text { Score }\end{array}$ & $60-74$ & 6 & $20,69 \%$ \\
$\begin{array}{c}\text { Lower } \\
\text { Score }\end{array}$ & $31-59$ & 0 & $0 \%$ \\
$\begin{array}{c}\text { Poor } \\
\text { Score }\end{array}$ & $0-30$ & 0 & $0 \%$ \\
\hline
\end{tabular}

From the table analysis above, the students' speaking skill of English lesson was still low. From the criteria, 23 students got upper score or it was only $79,31 \%$. In another side 6 students lower score or it was $20,69 \%$. From the criteria, 23 students got successful score or it was $79,31 \%$. Then 6 students got unsuccessful or it was $20,69 \%$. It could be concluded that the students' speaking skill in English lesson was still low. The spread of score was presented in the frequency distribution table 4.6 below:

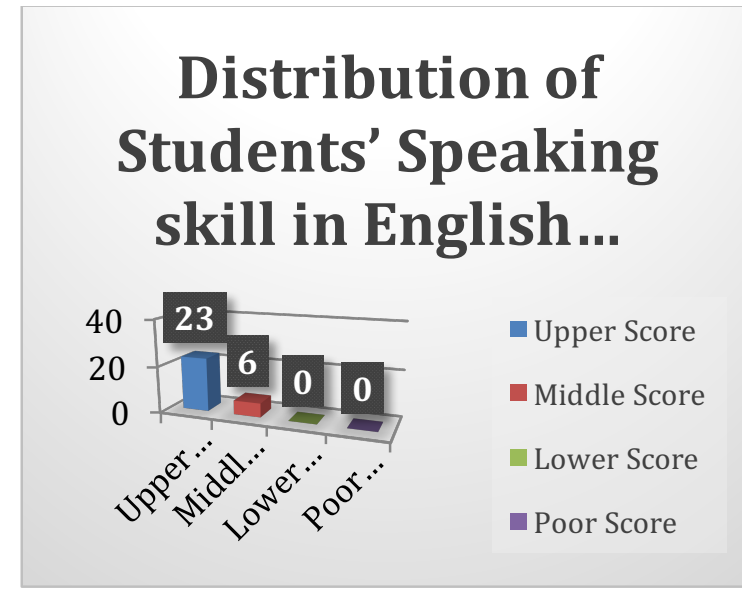

Figure 2. Distribution of Students' Speaking skill for Post-Test

It can be seen in the diagram above $90 \%$ of students increase the score after the writer applied Puppets Games in teaching speaking. The students can speak English using puppets because that activity is very fun for them.

\section{The Analysis of Data}

Based on the result analysis of the data above it is explained that before giving the treatment the total of students' pretest score was 1692 and after giving the treatment the total of students' posttest score increased to 2233 and the comparison score between pretest and posttest was 548. So, the determine mean of difference score of pretest and posttest was 18.89 and the result of (pretest-posttest) - determine) or $\left(x_{j}-x_{i}\right)$ $-\bar{D})$ was -0.1 and (pretest-posttest) determine $){ }^{2} \quad\left(\left(x_{j}-x_{i}\right)-\bar{D}\right)^{2}$ was 1691.9509. in addition, the result of Ttest calculation before 13.11 was obtained in the degree of freedom (df) of 29 (29-1=28).

With the degree significant $5 \%$, it gained score of 2.048. The result of calculation above showed that $t_{0}$ ( $t$ observation) $13.090>\mathrm{t}_{\mathrm{t}}$ (t-table) 2.045 . Since the result $t_{0}$ higher than $t_{t}$ the 
alternative hypothesis $\left(\mathrm{H}_{\mathrm{a}}\right)$ was accepted and the null hypothesis $\left(\mathrm{H}_{\mathrm{o}}\right)$ was rejected. From the explanation, it can be concluded that there was a significant difference between the students' result of the experimental class before and after this strategy was applied. The mean result of the pre-test was 58.34. Meanwhile, the mean result of the students' post-test was 77 .

\section{CONCLUSION}

حis study had quasi-experimental which was intended get effectiveness of using puppets games in teaching speaking at tenth grade senior high school. Based on previous chapter, the experimental class result had different significance between before and after which writer applied the strategy. Then, after seven weeks treatments students get higher score on the post-test result than the pre-test result. The result of the pre-test was 58.34 and the result of post-test was 77 . Besides, the $\mathrm{t}$ observes as significantly than the $t$ table at 13.11 . The calculation showed $13.090>2.045$ (significance $5 \%)$. It means that the Null-hypothesis $\left(\mathrm{H}_{0}\right)$ is not effective and the alternative hypothesis $\left(\mathrm{H}_{1}\right)$ is effective. It can be concluded that Teaching speaking using puppets games is effective to improve speaking skill at the tenth grade of SMA PerjuanganDepok.

\section{REFERENCES}

Blestein, T., \& Lewis, M. (2015). One-onOne Language Teaching and Learning: Theory and Practice. Cambridge, UK: Cambridge University Pres.

Celce-Murcia, M., Brinton, D., \& Snow, M.
A. (2014). Teaching English as a Second or Foreign Language. New York: Heinle Cengage Learning.

Goh, C. C. M., \& Burns, A. (2012). Teaching Speaking: Holistic Approach. New York: Cambridge University Press.

Hughes, R., \& Szczepek Reed, B. (2017). Teaching and Researching Speaking. New York: Routledge.

Huyen, N. T. T., \& Nga, K. T. T. (2013). Learning Vocabulary through Games: The Effectiveness of Learning Vocabulary through Games. The Asian EFL Journal, 5(6). Retrieved from https://www.asianefl-journal.com/mainjournals/learning-vocabularythrough-games-the-effectiveness-oflearning-vocabulary-throughgames/\#squelch-taas-tab-content-01

Kidspot. (2016). 14 Fun Puppet Activities For Kids. Retrieved from https://www.kidspot.com.au/things -to-do/art-and-craft/14-fun-puppetactivities-for-kids/imagegallery/138250ddf6d59441cc1a061 cdc900b5a

Mayesky, M. (2011). Creative Activities for Young Children. Wadsworth Cengage Learning.

Narayanan, K. (2012). The Importance of Puppets. Retrieved from https://www.slideshare.net/kokilav aaninarayanan/the-importance-ofpuppets

Richards, J. C. (2012). The Language Teaching Matrix. Cambridge: Cambridge University Press.

Wikipedia. (n.d.). Puppet. Retrieved from https://en.wikipedia.org/wiki/Pupp et\#Types_of_puppet_and_puppetry

Wright, A. (2013). RBT: Creating Stories With Children. Oxford University Press. 
English Langülage in Focus (ELIF), 2 (1), 1-8. https://jurnal.umj.ac.id/index.php/ELIF 